\title{
Considering the marketing of higher education: the role of student learning gain as a potential indicator of teaching quality
}

\author{
Martyn Polkinghorne ${ }^{\mathrm{a}, \mathrm{b}}$; Gelareh Roushan ${ }^{\mathrm{b}}$; Julia Taylor ${ }^{\mathrm{c}}$ \\ ${ }^{a}$ Faculty of Health \& Social Sciences, Bournemouth University, Poole, UK; \\ ${ }^{b}$ Faculty of Management, Bournemouth University, Poole, UK; \\ ${ }^{c}$ Doctoral College, Bournemouth University, Poole, UK.
}

\begin{abstract}
The marketization of higher education has ensured that students have become consumers. As a result, students are demanding increased levels of information regarding potential university courses so that they can make informed decisions regarding how best to invest their money, time and opportunity. A comparison of the teaching quality delivered on different programs of study will be an important element of this decision-making process. The Teaching Excellence Framework proposes that teaching quality will be assessed by measures including the evaluation of student learning gain. This paper reflects on an analysis of consultation responses from key stakeholders across the UK higher education sector to determine how evaluating learning gain could be effectively achieved. Synthesizing these responses, ten key considerations regarding evaluating learning gain have been identified that together provide a unique perspective to ensure that any evaluation of student learning gain subsequently undertaken is relevant to the marketing of higher education.
\end{abstract}

Keywords: marketing; marketization; higher education; learning gain; student learning; teaching excellence.

\section{Introduction}

Due to the continued marketization of higher education, administrators operate in “a dynamic marketplace that offers students an array of educational options and alternatives” (Bristow \& Schneider, 2002, p.15). There are inevitable linkages between the marketing of higher education and the marketization of higher education (Nedbalova, Greenacre, \& Schulz, 2014), with the marketing being driven by the need to increase student numbers and reputation, and the marketisation being driven by the 
introduction of fees for home-based undergraduates (Palfreyman \& Tapper, 2016) and, in particular, by the offer of fee variations (McGettigan, 2013).

More specifically, if the marketization of higher education is about buyers (students) deciding where to spend their time and money on studying for a once-in-alifetime opportunity to obtain a degree level qualification, then the marketing of higher education needs to respond to this with provision of data relating to appropriate metrics, so that any student undertaking such a purchase can make an informed decision regarding their university choice. The student is the personification of market pressure (Molesworth, Scullion, \& Nixon, 2010), and so universities therefore need to respond accordingly to provide a justification on the basis of value for money. Palfreyman and Tapper (2016) state that:

"Universities should also be required to provide more information on how they determine their fee levels and should be more open to providing redress to students when they feel they have not been given the standard of education that they felt they were purchasing.” (p.51-52).

Existing external sources of information do exist, such as Key Information Sets, National Student Survey and Destinations of Leavers from Higher Education Survey results, which together aid a student to understand the differences between particular courses and institutions. However, it is also considered that there are many factors that students may wish to know about the quality of teaching that they will receive, as it is believed that this may be a contributing factor influencing their decision to 'buy' in their new role as a consumer of education.

The National Committee of Inquiry into Higher Education (Dearing, 1997) previously highlighted the connection between economic success and the teaching and learning provided by higher education. Future marketing of higher education will therefore be dependent upon the ability of individual institutions to demonstrate the 
levels of teaching excellence delivered to past and existing students. However, it should also be recognized that excellence in teaching is, in fact, a value-laden concept of increasing global significance (Clark, 1998), and so the ability of a higher education institution to present valid and reliable data regarding its teaching quality will help to reinforce brand image and reputation, both of which are of increasing significance when attracting both home-based and international students.

Achieving teaching excellence is therefore important for both the marketing and marketization of higher education, but how such "excellence is defined, operationalized, and measured in relation to teaching and learning still lacks a clear consensus” (Gunn \& Fisk, 2013, p.9). How teaching excellence is viewed in practice, and the different perspectives that exist, can often create tensions resulting in conflicting demands within an educational institution (Brew, 2007). These tensions need to be considered so that any subsequent indication of teaching quality is based upon an agreed understanding, i.e., if levels of teaching excellence at a particular institution are going to be utilized as part of a student's consumer-based decision-making process, then all institutions need to be evaluating teaching excellence in the same way so that realistic comparisons can be made.

With UK higher education now competing in the global marketplace, there is a further requirement for it to respond to an even wider range of controls and opportunities. However, as Jongbloed (2003) observes, higher education "still does not seem to meet the expectations of many citizens, especially [those of] the students, their parents and private businesses” (p.113).

In addition, as reflected in the Competition and Markets Authority's open letter to universities (2016), due to the on-going process of marketization, students in the UK 
higher education sector are now considered to be covered by consumer protection law. This change brings with it additional rights for the students, and new requirements and responsibilities for higher education institutions, such as the need to ensure that only “clear and upfront information [is provided] to prospective students” (p.2) concerning a range of factors including policies, modules, fees and additional costs. Bristow and Schneider (2002) note the importance of customer orientation which they argue is central to the successful implementation of marketization. This reflects Drucker (1954) who determined that, in a competitive market with intelligent consumers, understanding and satisfying the needs of the customer (the student) is as important as addressing the needs of the company (the university). These factors, together with recent increases in student fees, have been the drivers behind the UK Government's proposed introduction of a Teaching Excellence Framework (TEF) which aims to evaluate the quality of the teaching being delivered at higher education institutions. The aspirational goal is that students and other stakeholders can be better informed, and the primary channel for informing them is through the marketing of higher education.

As a direct result, in 2016, public and private sector organizations from across the higher education sector in the UK were invited to respond to the Government's consultation on the proposed Teaching Excellence Framework as detailed in the Higher Education Green Paper (Department for Business, Innovation \& Skills, 2015a). All responding organisations were asked to provide their institutional views and opinions regarding the operation, implementation and perceived value of the plans for the Teaching Excellence Framework. Alongside teaching quality and the learning environment, student learning outcomes/learning gain were proposed as being a key indicator of teaching and learning excellence. However, unlike teaching quality, the learning environment and learning outcomes, which are all well-defined within the 
Government's proposals for the Teaching Excellence Framework, it was apparent that there was much less detail and understanding regarding the nature and definition of learning gain.

By synthesizing these consultation responses together, it has been possible to develop a clear indication of how the sector considers that the evaluation of student learning gain could/should be achieved in practice. This paper discusses the issues raised to determine the role that the evaluation of student learning gain may have in the context of the future marketing of higher education in the UK, and proposes ten key considerations that any such evaluation of learning gain should consider if it is to be relevant and 'fit for purpose'.

\section{Methodology}

This was a mono-method qualitative research study, based upon a cross-sectional time horizon, and employing the recursive abstraction process (Polkinghorne, 2015) to review content of, and distil salient information from, the consultation responses considered. All consultation responses considered are available from open access sources via the internet. The responses were considered to be narrative-based submissions and so an inductive approach, and the philosophical position of interpretivism (Saunders, Lewis, \& Thornhill, 2012) was used throughout this study. A non-probability homogeneous sampling technique was applied, and the forty consultation responses identified for consideration were independently analyzed and reviewed by an experienced university-based team of researchers. These responses represented a diverse range of universities, student bodies, professional associations and representative organizations from across the higher education sector. It should be noted 
that the Russell Group and the University Alliance each made a submission representing the collective views of their member universities.

During the analysis, consideration was only given to sector views that related directly to questions asked by the UK Government within the official consultation process regarding, or impacting directly upon, student learning gain. These questions were:

- How can information from the TEF be used to better inform student and employer decision making?

- Do you agree with the focus on teaching quality, learning environment, student outcomes and learning gain?

- Do you agree with the proposed approach to the evidence used to make TEF assessments - common metrics derived from the national databases supported by evidence from the provider?

The recursive abstraction process of summarizing, collapsing and then grouping the data (Polkinghorne \& Arnold, 2014) was applied to identify themes and trends within the selected consultation responses, and to gain an understanding of the sector's combined views with respect to student learning gain. The resulting six over-arching relevant themes that emerged from the data were:

(1) Theme 1 - Justifying the interest in learning gain,

(2) Theme 2 - Learning gain and learning outcomes,

(3) Theme 3 - Data sources used to calculate learning gain,

(4) Theme 4 - Learning gain and student satisfaction, 
(5) Theme 5 - Learning gain and teaching,

(6) Theme 6 - Learning gain and employers.

Each of the identified over-arching themes was then considered in relation to the marketing of higher education to formulate a reflection of the sector's perspective on using learning gain as an indicator for teaching excellence.

\section{Theme 1 - Justifying the Interest in Learning Gain}

For the benefit of students, the Teaching Excellence Framework proposes to use a range of metrics (including the evaluation of learning gain) to determine the quality of teaching across the higher education sector. If learning gain data is to be provided to potential future students as a means of marketing higher education with respect to the quality of course provision, then it is essential that an agreed definition of what learning gain represents, and how it will be evaluated, is established.

Although student bodies support in principle the Teaching Excellence Framework's aim of improving teaching quality, significantly it should be noted that they have concerns regarding the practical nature of how it will work, and the value to themselves as both students and consumers of education:

\footnotetext{
"We agree that teaching quality, learning environment, student outcomes and learning gain are important factors in the concept of teaching excellence. We believe quality often reflects frequent, active contact with academic staff, and useful feedback by academic staff on written work. However, we do not believe these concepts can be easily quantified. We do not think that sector-wide metrics will improve the teaching quality experienced by our students. They will create more bureaucracy and may actually distract from our more focused work on promoting quality teaching.” (Oxford University Student Union, 2016, p.10).
} 
Universities and other representative bodies from across the higher education sector have noted the need for any such metrics to be fit for purpose, which, in this context, means that metrics must be valid and robust. In particular, the Royal Geographical Society (2016) considers that to be useful to students as part of their consumer-based decision-making process, the metrics will need to be credible and understandable, and, to provide a complete picture, they will need to be comprehensive and current. Furthermore, Lancaster University has expressed concerns that any metrics used need to be "measures of the quality of teaching offered by institutions rather than measures of institutional prestige, such as entry grades and graduate earnings” (Ashwin, 2015). It is therefore clear that there are many factors that can be measured or evaluated, and the choice of factors is very subjective. However, only some factors have the potential to provide a useful indication of learning gain, and so a careful and thoughtful selection process is required to determine those that are best suited. In other words, the data which is easiest to obtain may in fact be the least appropriate for inclusion in the evaluation of student learning gain. Such data may not be useful to support the marketing of higher education, and may also be only minimally applicable in the context of marketization.

The Teaching Excellence Framework itself (Department for Business, Innovation \& Skills, 2015a) has a focus upon three elements defined as representing the core of teaching excellence, these being:

1) Teaching quality,

2) Learning environment,

3) Student outcomes and learning gain. 
However, according to the Committee of University Chairs (2016), it is unclear if these three elements can be meaningfully aggregated to create an overall measure of a university's teaching excellence. If this is true, then the implication is that there are additional dimensions of teaching quality not currently being considered, which need to be identified and encapsulated within the overall assessment process.

Use of learning gain statistics could also be used within the marketing of higher education to employers. The Engineering Employers Federation (2016) has recognized that learning gain is of particular importance to employers, and so companies also need to be reassured that the metrics used for calculating learning gain are valid and reliable. However, this discussion regarding the concept of evaluating learning gain does not take into account that it is currently unclear to the higher education sector what is actually meant by learning gain, or how this could be measured in any meaningful way. According to the University of Cambridge (2016), there is currently "no credible metric for measuring learning gain in a consistent way across the sector” (p.15), which is clearly problematic. This view is supported by the Higher Education Policy Institute (2016), which states that "while we have measures of [learning] outcome, we do not yet have any usable measures of learning gain” (p.16). This, of course, raises two important questions:

1) How can we measure something that is not understood?

2) How can we justify using the results of a process within the marketing of higher education when it is based upon such high levels of ambiguity?

Whilst both the Engineering Professors’ Council (2016^^ and the Association of Heads of University Administration (2016) support the view that there is no agreement as to what a measure of learning gain would look like in practice, there are also 
additional concerns raised by King's College London (2016) in relation to the viability of even developing a valid measurement of learning gain in the short term and, based on international experience of trials elsewhere, the Quality Assurance Agency for Higher Education (2016) highlights that it may be "premature to expect that sufficiently robust and reliable measures of learning gain can be developed in the immediate future” (p.14). Since evaluation of learning gain is highly complex with multiple variables, the Committee of the Association of National Teaching Fellows (2016) considers that before the higher education sector can even start to consider its inclusion as a metric in the Teaching Excellence Framework, consensus must be achieved on what learning gain actually is, and once this has been achieved, the Royal Society (2016) reflects that time will therefore be required to develop and implement valid metrics. Considering the implications of this, whilst the marketization of higher education may demand that we provide data to support teaching quality claims, the marketing of higher education cannot, and should not, be seen to be using data not considered to be robust and 'fit for purpose'.

As a result, there is considerable anecdotal evidence that the higher education sector has the appetite to evaluate student learning gain, but the sector has also demonstrated a lack of confidence in how learning gain will be assessed to ensure that results obtained are valid and reliable. This is problematic in the context of marketing higher education as, unless the data is reliable, it cannot be utilized effectively. Nevertheless, however it is measured in the future, there is widespread agreement from the consultation responses reviewed that the assessment of learning gain must not be an administrative burden to the institution, or to the students themselves, and upon this point there is a consensus. In summary, the key issues raised by Theme 1 are: 
- The evaluation of learning gain must be robust and valid if it is to provide a suitable indication of an institution's teaching quality that can be used in marketing and promotion,

- A new model for evaluating the learning gain of students may be necessary if the higher education sector is to achieve the Teaching Excellence Framework's objective of identifying good quality teaching,

- Any proposal to measure student learning must not become a bureaucratic burden for either institutions or students.

\section{Theme 2 - Learning Gain and Learning Outcomes}

Whilst there is an expectation that the Teaching Excellence Framework will provide accurate information for students about the nature of learning and teaching at prospective universities in order to aid informed decision making, there is also evidence reported by the Higher Education Academy (2016) that even current sources of information, e.g., Key Information Sets, are not being accessed by the majority of students. To be valuable as a component supporting the marketing of higher education, the need to provide the right information, i.e., information that is desired and valued by students, is clearly critical.

Although the Teaching Excellence Framework does not specifically define learning gain, the Higher Education Report for the Higher Education Funding Council for England defines learning gain as the "distance travelled by [a] student across two points in time in terms of skills and competencies, content knowledge and personal development" compared to a learning outcome which is a "learning objective or student achievement” (McGrath, Guerin, Harte, Fearson, \& Manville, 2015, p102). This definition is useful for this research study as it demonstrates that a learning gain is 
different from a learning outcome, because learning gain is about the development of a student, and learning outcomes are about the achievements of a student. In addition, according to the University of Oxford (2016), the student outcomes and learning gain currently discussed in the Teaching Excellence Framework are "more focused on inputs and outcomes, and as such are less reliable proxies for teaching quality” (p.7).

Even though student outcomes and learning gains are often grouped together as if similar in nature, the Higher Education Policy Institute (2016) states that learning outcomes are not well predicted by the quality or quantity of educational processes, whilst learning gains can be. This supports the argument by Royal Holloway (2016) that learning gain and learning outcomes should be dealt with differently in the context of the Teaching Excellence Framework and the marketing of courses, and therefore it is important that a clear differentiation between student learning outcomes and learning gain needs to be achieved. Students need to clearly understand the expectation for deliverables from the organization, and also identify a similar expectation for deliverables from themselves (Ng \& Forbes, 2009). For the purposes of marketing higher education, data regarding students achieving learning outcomes has little merit as it is directly related to a combination of aptitude, attitude and prior knowledge. However, the learning gains made by students are more relative in nature, and therefore, even though past learning gains are no guarantee of future learning gains, this form of data may provide a useful indicator to aid the overall selection process and to ultimately aid the decision making of future potential students. In summary, the key issues raised by Theme 2 are:

- An understanding of the learning of existing students at a university may influence the decision of new students when selecting a course, 
- Learning gains are not the same as learning outcomes.

\section{Theme 3 - Data Sources Used to Calculate Learning Gain}

Robinson and Sykes (2014) have previously reported that:

"in the UK, the marketisation of Higher Education (HE) increasingly constructs students as 'customers' rather than 'learners'. Prospective students are faced with an array of published material to enable them to compare and contrast the 'products' on offer from UK institutions ... which provides at-a-glance information about each programme to help inform the choice of university”. (p.35)

Currently, the Teaching Excellence Framework proposes basing the calculation of learning gain upon such data already available from existing sources such as the National Student Survey (NSS) and the Destination of Leavers from Higher Education survey (DLHE). However, there is limited scope for reassessing this data to reveal currently unknown information and trends relating to teaching quality. Considering the aspiration for data that can be used to underpin the marketing of higher education to address the marketization needs, there is a need for new data that will reveal to students the likely impact that a particular course will have on their development. There is evidence supported by the British International Studies Association (2016) that the higher education sector considers that developing and piloting suitable new measures for learning gain is preferred to basing assessments on existing indicators, which they consider are only proxies of teaching excellence. The Royal Society of Chemistry (2016) concurs that indicators currently being considered do not provide direct evidence for teaching quality, learning environment, student outcomes or learning gain. The Royal Academy of Engineering (2016) supports this perspective and considers that the metrics proposed, such as Destination of Leavers from Higher Education data, will need to be treated with particular care if used to determine teaching excellence. 
Even though there are increasing demands, due to the marketization of higher education, for information upon which informed decisions can be made, considering the questions in the National Student Survey that relate specifically to teaching, it is unclear how these could be used to make a reasonable determination of learning gain in any meaningful way, since the actual questions were relatively simplistic in approach, including statements such as:

1) Staff are good at explaining things,

2) Staff have made the subject interesting,

3) Staff are enthusiastic about what they are teaching,

4) The course is intellectually stimulating.

Recent revisions to the questions from 2017 have clearly added greater depth of enquiry, but not with respect to evaluating learning gain:

1) My course has provided me with opportunities to explore ideas or concepts in depth,

2) My course has provided me with opportunities to bring information and ideas together from different topics,

3) My course has provided me with opportunities to apply what I have learnt.

The Royal Geographical Society (2016) rightly highlights that external factors such as university location could have either a negative or a positive impact upon any graduate employment prospects and earning potential data collected. Student satisfaction is also linked to background, social networks and regional issues. According to the University of Southampton, other factors such as accommodation and timetabling 
will also impact upon NSS results (University of Southampton, 2016), but in the view of the University of Brighton, one way to overcome such issues may be to ensure that data used for the measurement of learning gain includes contextual data (University of Brighton, 2016).

Of particular relevance is that, even though the Teaching Excellence Framework is proposed by the Government as a mechanism for providing students with more valuable information, student groups themselves do not anticipate that the data sources proposed are going to provide useful and helpful information which will enable them to make informed choices about where and what to study. In particular, the National Union of Students (2016) considers that the Teaching Excellence Framework will be limited in scope and value if it is to be based upon the very existing data sources that the Government has previously criticized as part of its justification for introducing the Teaching Excellence Framework in the first place. Therefore, it is uncertain if the proposed Teaching Excellence Framework can actually measure teaching excellence. According to Scott (2015):

"All metrics are open to manipulation. But these are especially vulnerable. NSS scores are now ruthlessly "gamed", because of their impact on league tables ... none of these metrics, or any others that might be incorporated, actually measures teaching excellence. So the TEF cannot do what it says on the tin” (The Guardian, 2 November).

If this view is correct, and in fact, the Teaching Excellence Framework will not be able to measure teaching quality, then from the perspective of marketing higher education, care must be taken to ensure that a fair representation of courses and institutions is achieved. It can therefore be concluded that, from the higher education sector view presented, the evaluation of student learning gain is a complex problem requiring the sensible deployment of carefully identified data. Use of information from 
existing data sources should therefore be avoided, as it will not provide the level of detail required to meaningfully evaluate the learning gain of students. It should also be remembered that "regardless of what universities think students want, it is clear that the student is the consumer of higher education and students' satisfaction in the consumption of a university experience is important” (Ng \& Forbes, 2009) and must therefore remain at the forefront of our thinking. In summary, the key issues raised by Theme 3 are:

- Any measure of the learning of students should disregard external factors not linked to teaching quality, and over which institutions have no control,

- The effects of 'gaming' upon the data collected for the purposes of evaluating student learning must be minimized.

\section{Theme 4 - Learning Gain and Student Satisfaction}

According to the Royal Academy of Engineering (2016), a university education is about expanding the mind of students and stretching their horizons. This is a key marketing message and is aligned to the second principle of marketing, i.e., cross functionality (Bristow \& Schneider, 2002). This process may be uncomfortable for the student and therefore may often not be immediately valued, which presents a typical marketing dilemma, i.e., in the case of marketing of higher education, the truth that the customer needs to hear is not always the truth that the customer wants to hear, and conflicts with the accepted marketing stance that the needs of a consumer must be met effectively (Kotler \& Keller, 2006).

Such contradictions do occur in education; for example, team working is an aspect of learning that some students may find difficult, but it is also of enormous value 
to a student's employability, and to society more widely. Crucially, teaching excellence is not the same as student satisfaction (Royal Academy of Engineering, 2016). Any evaluation of teaching excellence, including student learning gain, therefore needs clarity on this issue to avoid an inaccurate interpretation of results. The Council for the Defence of British Universities (2016) notes that in the Higher Education Green Paper there is no evidence presented to support the view that student satisfaction and teaching quality are even linked in any way. This is further supported by the British International Studies Association (2016) which states that "student satisfaction is not necessarily a measure of teaching quality, but of a range of other, wider factors as a course can be well designed with appropriate aims and outcomes, but unpopular due to its difficulty” (p.8). Furthermore, a study by Gibbs, reported by the Higher Education Policy Institute (2016), observes that:

“just as with students' persistent obsession with class contact hours, which do not predict learning gains, their views about what they want are sometimes flatly contradicted by research evidence about what is good for them. Satisfaction is a difficult measure to interpret and there is no research evidence that satisfaction predicts learning gains” (p.14).

The direct implication is that by providing students with what they want, we may not be providing them with what they need, and as such, this needs to be accounted for in any evaluation of learning gain. The Council for the Defence of British Universities (2016) has identified that "while students often claim to want more contact hours, this leads to more assisted learning, and consequently less independent learning” (p.7), which reduces the potential for learning gain. In addition, "higher contact hours may be inversely correlated with educational excellence in many cases, since independent learning is central to progress and achievement in higher education” (p.8). 
Learning gain does not, therefore, appear to depend on contact time, and may only be a partial indicator of teaching quality. As identified by the Committee for the Association of National Teaching Fellows (2016), "multiple factors impact on ipsative development, of which the quality of teaching is only one” (p.13). The Higher Education Policy Institute (2016) expands upon the range of non-teaching related factors that need to be considered, and reports that "outcome measures are highest in institutions with high student entry standards based upon a function of institutional reputation. They do not predict student learning gains. Neither do they predict the use of educational practices known to improve learning gains” (p.16).

Reviewing the National Student Survey results published by the Higher Education Funding Council for England (2015), and based upon a combined result from those responding that they definitely, or mostly, agreed with the questions, $87 \%$ of students expressed their satisfaction with the teaching they have received. However, the British International Studies Association (2016) also reflects that less than 50\% of students considered their university education to be good value for money, which, it can be argued, represents a dissatisfaction with the fees system rather than with the quality of the teaching provided.

It can therefore be considered that the evaluation of learning gain must take into account the wider elements of education at higher education level, such as the development of the individual as an autonomous learner, and should not seek to take into account external elements such as retention and destination data, as these are factors outside of the learning environment with no direct relationship to teaching. In this way, by employing such methods for describing the performance of academic learning, the marketing of higher education can become more representative of key 
drivers without incurring the negative connotations connected with portraying education in terms detrimental to attracting increased student numbers. The education delivered to students is often transformative in nature, and this change in perceptions, values and understanding needs to be captured through the evaluation of learning gain to ensure that any data generated is suitable upon which to base higher education marketing activities. In summary, the key issues raised by Theme 4 are:

- Student learning, resulting from good teaching, is not the same as student satisfaction, and should therefore not be treated as if they are the same thing,

- Students need to be developed into autonomous learners,

- Good teaching changes the perceptions and values of students.

\section{Theme 5 - Learning Gain and Teaching}

"Having a marketing orientation does not merely mean quality assessments, processes, systems, and promises of a pedigree education. It means understanding the elements of delivering an outstanding service” (Ng \& Forbes, 2009, p.58). To achieve this level of outstanding service, differing strategies can be implemented. For example, teaching methods vary between different universities and subjects, of which the polar opposites include the Oxbridge intense tutorial system and the Open University distance learning format. The Institute of Mathematics and its Applications (2016) has identified that if the Teaching Excellence Framework is institution-based as proposed, then it is not clear how it will convey useful information about "the quality of teaching for any particular discipline” (p.1). Supporting this, University College London (2016) notes that an alternative discipline-specific context is important, and the Committee of the National Teaching Fellows (2016) reflects that such an approach will help to address variations between the performances of different departments within a university. 
The Royal Historical Society (2016) is clear on the importance of recognizing the pedagogical subject differences, a view also supported by the work undertaken by Shulman (2005). The University of Cambridge (2016) therefore reflects that it would be highly damaging to the higher education sector to create a Teaching Excellence Framework that diminishes this diversity which links directly to the brand value of the university (Bennett \& Ali-Choudhury, 2009).

Durham University (2016) rightly highlights that education is part of a rich and complex experience of development opportunities for a student, which is important for their future employability, and to their role as an informed and responsible global citizen. The Royal Society (2016) raises the important issue that there is a risk that a focus on teaching inputs, instead of developing independent learners, will mean that:

\footnotetext{
"Teaching styles that have more immediate and measurable impact may become favoured over teaching that has less easily measured outcomes. Teaching aimed at developing independent thinking and interdisciplinary approaches are two areas that could be at risk from imperfect measures" (p.5).
}

From the views presented, it is evident that even if subsequently amalgamated at discipline or institutional levels, the determination of learning gain must be as specific to the student as possible, and focused at the lowest possible level to capture diversity, and so reflect the brand value of a university within its marketing and awareness raising activities. Its calculation needs to be flexible so that it can accommodate different learning styles and teaching methods, and the introduction of learning gain assessment must stimulate better teaching and not inhibit innovation and experimentation. In summary, the key issues raised by Theme 5 are:

- The definition of good teaching varies between subjects and disciplines, 
- Student learning relates to a range of developmental opportunities both inside and outside of the classroom.

\section{Theme 6 - Learning Gain and Employers}

Bennett and Ali-Choudhury (2009) report that "Universities often infer promises about a [student's] job and career prospects on graduation” (p88), yet from the perspective of the Engineering Employers Federation (2016), there is increasing concern around the quality and quantity of graduates leaving the higher education system and entering industry. Employers therefore wish the Teaching Excellence Framework to be developed in a way that enables employers to establish the employability or 'workreadiness' of graduates. However, whilst employers may be interested in the value of students, the University of Brighton is firm in its belief that it is unclear if employers are seeking any level of detail about teaching specifically (University of Brighton, 2016).

Reviewing the Destination of Leavers from Higher Education results for 2013/14, of the 424,375 leavers from UK universities whose destination is known, $71 \%$ were working, $12 \%$ were studying, $6 \%$ were undertaking a combination of work and study, $5 \%$ were travelling etc., with the remaining $6 \%$ being unemployed. In the UK, the unemployment rates vary from under $1 \%$ in medicine to $11 \%$ in computer science. Of those working, 66\% were in professional graduate level jobs and 32\% were in nonprofessional roles, of which a third undertaking non-professional jobs work in sales and customer service (Higher Education Statistics Agency, 2015). In addition, graduate labor market figures released by the Department for Business Innovation and Skills for Q1 and Q2 of 2015 reveal that graduate employability is 87\%, which is the highest since 2007 (BIS, 2015b), and the unemployment rate of 4.4\% among young graduates is the lowest Q2 rate since the 2.7\% recorded in 2008 (2015c). 
These figures raise questions regarding the need for employers to have greater understanding of students' educational experience, as it can be argued that the result is unlikely to be more graduate employment given the current high levels, but instead will be graduate displacement, i.e., the introduction of a Teaching Excellence Framework may enable the best employers to select the best graduates more easily, leaving other employers to select from the remainder of each student cohort, with no overall advantage for the UK economy.

Employability measures are affected by student quality, as well as by a wide range of additional variables, many of which are not under the control of an educational institution. Goldsmiths (2016) reports that, to be a valuable resource to employers, the Teaching Excellence Framework must therefore also account for the information "that employers actually use when making decisions” (p.3). Universities UK (2016) noted that a recent skills survey undertaken by Pearson Educational for the Confederation of British Industry (2015) identified that when recruiting graduates, the most important factors to employers were:

- Attitudes and aptitudes for work $89 \%$

- Relevant work experience/industrial placement 64\%

- $\quad$ Degree subject 55\%

- Degree class $17 \%$

- University attended $4 \%$

Degree subject is therefore not the top priority for businesses seeking to employ graduates. However, from an employer perspective, the Association of the British Pharmaceutical Industry (2016) is quite clear that any measure of learning gain utilized for the Teaching Excellence Framework will need to assess factors that directly relate to 
"the extent to which a course prepares a student for their future career" (p.5) and, as such, will be less about what students leave university with, in terms of knowledge, and more about how they have developed whilst at university. This links directly to the desire for graduates to have the right attitudes and aptitudes, as reported by the members of the Confederation of British Industry. However, considering this from a marketization perspective, graduates, as the consumers of education (Molesworth et al., 2010), are not seeking to develop their attitude and aptitude, and instead measure their own personal development by their grades and knowledge. However, it can also be argued that this is a misapprehension, and that we need to maintain the perspective that students are 'learners that actively consume educational processes' (Robinson \& Sykes, 2014, p.37) so that we can evaluate their personal development and growth.

To achieve this, it is reasonable to assume that assessment of learning gain should be an ongoing process throughout the university life of the student to record this development, with learning gain results feeding directly into the course development and review processes of the university to improve the standards of teaching provided, and to acknowledge good performance and methods. It can therefore be proposed that the factors used to determine learning gain must be relevant to institution, student and employer equally so that one evaluation can meet multiple objectives to ensure that brand values are supported. In summary, the key issues raised by Theme 6 are:

- Employers consider that they need a new measure to identify the ability of students leaving university,

- Existing employability measures are not a good indicator of student learning,

- Employers wish to know how students have development at university,

- Assessment of student learning should be an on-going process. 


\section{Discussion}

If a university's brand is truly a representation of distinguishing features, as reported by Bennett and Ali-Choudhury (2009), then the brand itself is a good starting point to provide an indication of potential learning to help potential new students make sensible decisions and their choice of university. However, as the University of Cambridge (2016) helpfully reminds us, the aim of a university is to enable students to grow into thoughtful and critical citizens which are potentially difficult concepts to capture within a brand. Nevertheless, a valid and robust indication of student learning gain achieved by existing students on a course, or at an institution, does have the potential to become a powerful marketing tool that universities will almost certainly be delighted to exploit.

It has been reported by the Higher Education Policy Institute (2016) that the current university outcome measures widely publicized are substantially influenced by the quality of students, and not the quality of the education they have experienced, with the result that there is broad consensus that data from existing sources should be avoided when considering the quality of teaching and learning. The Royal Geographical Society (2016) therefore presents the case that robust and reliable metrics relating to learning gain need to be developed to support the implementation of the Teaching Excellence Framework.

A widely held point of view presented by the Committee for the Association of National Teaching Fellows (2016) is that metrics that do not represent learning enhancement experienced by students at a university should not be included in the Teaching Excellence Framework's assessment of teaching quality/student learning. There is also common agreement that any metric used in the Teaching Excellence Framework must provide a true measure of teaching excellence. The University of 
Cambridge (2016) expands on this point to suggest that "better still from the students' perspective, it should also be a measure of learning excellence” (p.4) which is an important differentiation between teaching and learning. Also, if the Teaching Excellence Framework is to have any value, then it must be recognized by students as being a viable indicator of teaching quality; and yet the National Union of Students (2016) has expressed concern that "many of the proposed metrics for the TEF are poor indicators of teaching quality and are at substantial risk of gaming” (p.3). In other words, this supports the view that the Teaching Excellence Framework in its current form is unlikely to lead to meaningful improvements in teaching quality. This is a view also supported by the Higher Education Policy Institute (2016) which states that "outcome measures are substantially influenced by the quality of students and do not tell us much about the quality of the education they experienced” (p.15).

The Institute of Mathematics and its Applications (2016) reminds us that higher education institutions also differ greatly "not only in their demographic profile, but in their mission, and this diversity is a source of strength in the system” (p.1). This diversity is both at an institutional level and also at subject level. This needs to be recognized by the Teaching Excellence Framework, and it has been established that there is a requirement that metrics selected should be ones that support teaching excellence without creating the types of unforeseen consequences predicted by Lancaster University:

"One of the primary aims of the TEF is to improve the quality of teaching in universities. In order for this to happen the system needs to be designed so that the assessment and measurement of quality lead directly to changes in teaching practices. Without this careful design, the TEF is far more likely to lead to institutional gaming than changes in teaching practices” (Ashwin, 21 Dec, 2015). 
Learning gain is notoriously difficult to measure. The University Alliance group proposes that it may require a phased introduction over a period of time (University Alliance, 2016), and the Russell Group supports the case that any approved measures need to enable universities to demonstrate their diversity (Russell Group, 2016), an approach since reflected in the Higher Education White Paper (Department for Business, Innovation \& Skills, 2016a).

In addition, Universities UK (2016) remind us that learning gain assessments are in their infancy and will require significant development before a standardized approach that takes institutional and subject level variations into account can be considered.

Whilst a difference between student learning outcomes and learning gain has been established in principle, the University of Southampton is clear that these remain difficult to quantify in terms of teaching excellence, as the largest determinant is actually the quality of student (University of Southampton, 2016). It has therefore been established that there is concern across the sector regarding the ability of the Teaching Excellence Framework to actually determine any realistic evaluation of teaching quality (including student learning gain), but that if the results are to be used in any meaningful way, then there are a range of important factors that have been identified by this study, and that can now be acknowledged and discussed.

The need for evaluating student learning gain, and its role in providing helpful data that can be used within the future marketing of higher education in the UK as well as in supporting the need for students to make informed decisions as part of the ongoing marketization of higher education, has been established. However, reflecting on the points discussed in this paper, from this research study it has been possible to distil ten key considerations (Table 1) that summarize the main concerns raised by the UK higher 
education sector with regard to the evaluation of student learning gain. Together, these ten considerations create an informed perspective on how we should undertake such an evaluation, and what impact such data can have to support the marketing of higher education and to address issues raised by the marketization agenda.

To support the marketing of Higher Education, and to provide the level of data increasingly demanded by students due to the ongoing marketization of higher education, any measure of learning gain implemented needs to be both valid and appropriate, and therefore should comply with the following ten key considerations, i.e., the evaluation of learning gain must:

1. Require minimal administrative effort from staff and students,

2. Focus on learning gain and not learning outcomes as they are different,

3. Avoid using existing data sources which are too general,

4. Support the development of students as autonomous learners,

5. Ignore external factors over which teaching has no influence,

6. Capture the diversity of subjects,

7. Accommodate variations in teaching styles,

8. Support improvements and innovation in teaching,

9. Form part of the ongoing course review process,

10. Be relevant to institution, student and employer so that one assessment can meet multiple objectives.

Table 1. Ten key considerations for evaluating student learning gain to support the marketing and marketization of UK higher education 
As a sector view, this raises many issues and concerns, some of which have not previously been presented, and others which either support, or in some cases contradict, established understanding. However, these views represent many of the key stakeholders involved in UK higher education, and as such are an expression in qualitative terms of their own thoughts, concerns and feelings relating to this important issue.

\section{Conclusions}

From this review of forty responses to the UK Government's Higher Education Green Paper (Department for Business, Innovation and Skills, 2015a), representing a range of stakeholders from across the sector, it has become apparent that there is widespread agreement that the assessment of student learning gain has potential merit, but that such an evaluation should focus on actual learning gains related to the development of the student, and not be linked to learning outcomes concerned with the achievement of the student. For this purpose, use of data from existing sources should be avoided to ensure that learning gain assessments are relevant and meaningful. In addition, to be a useful indicator of teaching quality, student learning gain assessment should take into account wider elements of teaching at higher education level, and be focused at the lowest possible level to capture diversity, but should not consider external elements over which teaching has no direct relationship or influence.

Without becoming an administrative burden to the institution or to the student, any method for evaluating learning gain needs to be flexible to accommodate variations in learning styles and teaching methods, without inhibiting innovation and experimentation. It should also form part of the ongoing course development review processes of an institution. Because of this, the factors used to determine learning gain 
must be relevant to institution, student and employer so that, as much as is possible, one assessment can meet multiple objectives.

"We have suggested that marketisation of [higher education] can lead to outcomes-based evaluation which promotes changes in student identities” (Robinson \& Sykes, 2014, p. 39). To ensure that the results derived from any future evaluation of student learning gain are informative and fit for purpose, can be used both within the marketing of higher education, and can also address the questions asked by students and employers as part of the marketization agenda, these views need to be taken into account when formulating plans. It is suggested that they should be incorporated within the implementation of the Teaching Excellence Framework to ensure that its relevance and currency are sustainable in the longer term.

Already, the Teaching Excellence Framework is moving forward at a pace, evolving as it does so, building upon the thoughts and views of the higher education sector, and reflecting a changing political landscape. Initial Teaching Excellence Framework results for universities cited in this paper include 'Gold' for Oxford and Cambridge; 'Silver’ for Durham, King’s College London, Royal Holloway, University College London and Brighton; and 'Bronze’ for Goldsmith’s and Southampton (Times Higher Education, 2017). Pilot tests of several different methods for measuring the learning gain of students presented by McGrath et al. (2015), and subsequently summarized by Polkinghorne and Roushan (2017), are being undertaken. An alternative perspective of how learning gain could be evaluated instead has since been proposed (Polkinghorne, Roushan \& Taylor, 2017). How many of the proposed ten key characteristics identified in this paper will in time be implemented is as yet unknown, but already discussions regarding subject-based TEF are developing at an increasingly 
granular level. For example, if subject-based TEF is to be implemented, then how are subjects to be defined, and in what ways should they be categorized? These are important issues that will significantly influence the role of learning gain as an indicator for student learning, and so directly impact upon its suitability for use in the marketing of higher education. Only then, will the results of the Teaching Excellence Framework driven evaluation of student learning gain start to become a metric worthy of consideration by students and employers as part of the on-going marketisation of the UK higher education sector. Both stakeholder groups (students and employers) need to be able to understand what the term 'learning gain' means, and to have confidence that resulting data released by the higher education sector will be transparent and have relevance to their own specific needs, i.e. to students selecting a course of study and to employers recruiting graduates to join their organisation.

From a more generalized perspective, the process that the UK is now undergoing with regard to the evaluation of student learning gain across the higher education sector, and the lessons and developments that result, will have international implications. In particular, this may apply to both the US and European higher education sectors where these issues are also highly pertinent.

\section{References}

Ashwin. P. (2015, Dec 21). A response to the higher education green paper - Fulfilling our potential: Teaching excellence, social mobility and student choice. Lancaster University Blog. Retrieved from www.lancaster.ac.uk/educational-research/news-andevents/blog/paul-ashwin/a-response-to-the-green-paper/ 
Association of the British Pharmaceutical Industry (2016). Consultation response on the higher education green paper - Fulfilling our potential: Teaching excellence, social mobility and student choice. London: Author.

Association of Heads of University Administration. (2016). Consultation response on the higher education green paper - Fulfilling our potential: Teaching excellence, social mobility and student choice. Manchester: Author.

Bennett, R., \& Ali-Choudhury, R. (2009). Prospective students’ perceptions of university brands: An empirical study. Marketing for Higher Education. 19(1), 85-107.

DOI: $10.1080 / 08841240902905445$

Department for Business, Innovation \& Skills (2015a). Fulfilling our potential: Teaching excellence, social mobility and student choice. London: Author.

Department for Business, Innovation \& Skills. (2015b). Graduate labour market statistics January-March Q1 2015. London: Author.

Department for Business, Innovation \& Skills. (2015c). Graduate labour market statistics April-June Q2 2015. London: Author.

Brew, A. (2007). Integrating research and teaching: Understanding excellence. In A. Skelton, ed. International perspectives on teaching excellence in higher education: Improving knowledge and practice. Abingdon: Routledge.

Bristow, D., \& Schneider, K. (2002). Collegiate student orientation scale (CSOS): Application of the marketing concept to higher education. Marketing for Higher Education, 12(2), 15-34. Database: Education Source. 
British International Studies Association. (2016). Consultation response on the higher education green paper - Fulfilling our potential: Teaching excellence, social mobility and student choice. Aberystwyth: Author.

Committee of the Association of National Teaching Fellows. (2016). Consultation response on the higher education green paper - Fulfilling our potential: Teaching excellence, social mobility and student choice. York: Author.

Council for the Defence of British Universities. (2016). Consultation response on the higher education green paper - Fulfilling our potential: Teaching excellence, social mobility and student choice. London: Author.

Clark, R. (1998). Creating entrepreneurial universities: Organizational pathways of transformation. New York: Elsevier.

Committee of University Chairs. (2016). Consultation response on the higher education green paper - Fulfilling our potential: Teaching excellence, social mobility and student choice. Bristol: Author.

Competition \& Markets Authority. (2016). An open letter to higher education providers following the CMA's review of compliance with consumer protection law in the sector. London: Author. Retrieved from:

www.gov.uk/government/uploads/system/uploads/attachment_data/file/540253/highereducation-compliance-review-open-letter-to-providers.pdf

Confederation of British Industry. (2015). Inspiring growth. CBI/Pearson Education and Skills Survey 2015. Harlow: Pearson Education. 
Dearing, R. (1997). Higher education in the learning society. Report of the National Committee of Enquiry into Higher Education. London: HMSO. Retrieved from: www.leeds.ac.uk/educol/ncihe/

Drucker, P. (1954). The practice of management. New York, NY: Harper \& Row.

Durham University. (2016). Consultation response on the higher education green paper - Fulfilling our potential: Teaching excellence, social mobility and student choice. Durham: Author.

Engineering Employers Federation. (2016). Consultation response on the higher education green paper - Fulfilling our potential: Teaching excellence, social mobility and student choice. Birmingham: Author.

Engineering Professors' Council. (2016). Consultation response on the higher education green paper - Fulfilling our potential: Teaching excellence, social mobility and student choice. Godalming: Author.

Goldsmith's - University of London. (2016). Consultation response on the higher education green paper - Fulfilling our potential: Teaching excellence, social mobility and student choice. London: Author.

Gunn, V., \& Fisk, A. (2013). Considering teaching excellence in higher education: 2007-2013. A literature review since the CHERI report 2007. The Higher Education Academy (HEA) Research Series. York: Author.

The Higher Education Academy. (2016). Consultation response on the higher education green paper - Fulfilling our potential: Teaching excellence, social mobility and student choice. York: Author. 
Higher Education Funding Council for England. (2015). National student survey summary data for 2015. London: Author. Retrieved from www.hefce.ac.uk/lt/nss/results/2015/

Higher Education Policy Institute. (2016). Consultation response on the higher education green paper - Fulfilling our potential: Teaching excellence, social mobility and student choice. Oxford: Author.

Higher Education Statistics Agency. (2015). Destinations of leavers from higher education in the United Kingdom for the academic year 2013/14. Cheltenham: Author. Retrieved from www.hesa.ac.uk/sfr217

Institute of Mathematics and its Applications. (2016). Consultation response on the higher education green paper - Fulfilling our potential: Teaching excellence, social mobility and student choice. Southend-on-Sea: Author.

Jongbloed, B. (2003). Marketisation in higher education, Clark’s triangle and the essential ingredients of markets. Higher Education Quarterly, 57(2), 10. DOI: $10.1111 / 1468-2273.00238$

Kings College London. (2016). Consultation response on the higher education green paper - Fulfilling our potential: Teaching excellence, social mobility and student choice. London: Author.

Kotler, P., \& Keller, K. (2006). Marketing management. $12^{\text {th }}$ edition. India: PrenticeHall.

McGettigan, A. (2013). The great university gamble: Money, markets and the future of Higher Education. London: Pluto Press. 
McGrath, C., Guerin, B., Harte, E., Frearson, M., \& Manville, C. (2015). HEFCE report - Learning gain in higher education. Santa Monica, CA: RAND.

Molesworth, M., Scullion, R., \& Nixon, E. (2010). The marketisation of higher education and the student as consumer. Abingdon: Routledge.

National Union of Students. (2016). Consultation response on the higher education green paper - Fulfilling our potential: Teaching excellence, social mobility and student choice. London: Author.

Nedbalova, E., Greenacre, L., \& Schulz, J. (2014). UK higher education viewed through the marketization and marketing lenses. Marketing for Higher Education, 24(2), 178195. DOI: $10.1080 / 08841241.2014 .973472$

Ng, I., \& Forbes, J. (2009). Education as service: The understanding of university experience through the service logic. Journal of Marketing for Higher Education, 19(1), 38-64. DOI: $10.1080 / 08841240902904703$

Oxford University Student Union. (2016). Consultation response on the Higher Education green paper - Fulfilling our potential: Teaching excellence, social mobility and student choice. Oxford: Author.

Palfreymam, D., \& Tapper, T. (2016). The marketization of English higher education and the financing of tuition fees. Review of Education, 14(1), 47-55. DOI: 10.18546/LRE.14.1.06

Polkinghorne, M., \& Arnold, A. (2014). A six step guide to using recursive abstraction applied to the qualitative analysis of interview data. Poole: Bournemouth University. 
Polkinghorne, M. (2015). Two blue hats student guide to analysing qualitative interview data using recursive abstraction. Poole, UK: Kindle Direct Publishing in Association with Two Blue Hats.

Polkinghorne, M., \& Roushan, G. (2017). Assessing student learning: A comparison of existing methods for evaluating the learning gain of students. Poster presented at the 2017 CELebrate Regional Teaching and Learning Conference, Bournemouth University, June 13. Retrieved June 28, 2017 from http://eprints.bournemouth.ac.uk/29220/

Polkinghorne, M., Roushan, G., \& Taylor, J. (2017). Evaluating student learning gain: An alternative perspective. Poster presented at the 2017 HEA Surveys Conference, Manchester, May 11. Retrieved June 28, 2017 from https://www.heacademy.ac.uk/knowledge-hub/evaluating-student-learning-gain-alternativeperspective-hea-surveys-conference-2017

Quality Assurance Agency for Higher Education. (2016a). Consultation response on the higher education green paper - Fulfilling our potential: Teaching excellence, social mobility and student choice. Gloucester: Author.

Royal Academy of Engineering. (2016). Consultation response on the higher education green paper - Fulfilling our potential: Teaching excellence, social mobility and student choice. London: Author.

Royal Geographical Society. (2016). Consultation response on the higher education green paper - Fulfilling our potential: Teaching excellence, social mobility and student choice. London: Author. 
The Royal Historical Society. (2016). Consultation response on the higher education green paper - Fulfilling our potential: Teaching excellence, social mobility and student choice. London: Author.

Robinson, L., \& Sykes, A. (2014). Listening to students' views on NSS data for quality enhancement. Journal of Health and Social Care Education, 3(1), 35-40. DOI:

10.11120/hsce.2013.00035

Royal Holloway - University of London. (2016). Consultation response on the higher education green paper - Fulfilling our potential: Teaching excellence, social mobility and student choice. London: Author.

The Royal Society. 2016. Consultation response on the higher education green paper Fulfilling our potential: Teaching excellence, social mobility and student choice. London: Author.

The Royal Society of Chemistry. (2016). Consultation response on the higher education green paper - Fulfilling our potential: Teaching excellence, social mobility and student choice. London, UK: Author.

Russell Group. (2016). Consultation response on the higher education green paper Fulfilling our potential: Teaching excellence, social mobility and student choice. Cambridge: Author.

Saunders, M., Lewis, P., \& Thornhill, A. (2012). Research methods for business studies students ( $6^{\text {th }}$ ed.). Harlow: Pearson Education. 
Scott, P. (2015, November 2). Three reasons why the Teaching Excellence Framework won't work. Retrieved from https://www.theguardian.com/education/2015/nov/02/whyteaching-excellence-framework-tef-metrics-university-fees

Shulman, L. (2005). The signature pedagogies of the professions of law, medicine, engineering, and the clergy: Potential lessons for the education of teachers. In Talk delivered at the Math Science Partnerships (MSP) workshop: 'Teacher education for effective teaching and learning' hosted by the National Research Council's Center for Education. Retrieved from http://hub.mspnet.org/index.cfm/10531

Times Higher Education. (2017). Teaching excellence framework (TEF) results 2017. Retrieved from https://www.timeshighereducation.com/news/teaching-excellenceframework-tef-results-2017

Universities UK. (2016). Consultation response on the higher education green paper Fulfilling our potential: Teaching excellence, social mobility and student choice. London: Author.

University Alliance. (2016). Consultation response on the higher education green paper - Fulfilling our potential: Teaching excellence, social mobility and student choice. London: Author.

University of Brighton. (2016). Consultation response on the higher education green paper - Fulfilling our potential: Teaching excellence, social mobility and student choice. Brighton: Author.

University of Cambridge. (2016). Consultation response on the higher education green paper - Fulfilling our potential: Teaching excellence, social mobility and student choice. Cambridge: Author. 
University College London. (2016). Consultation response on the higher education green paper - Fulfilling our potential: Teaching excellence, social mobility and student choice. London: Author.

University of Oxford. (2016). Consultation response on the higher education green paper - Fulfilling our potential: Teaching excellence, social mobility and student choice. Oxford: Author.

University of Southampton. (2016). Consultation response on the higher education green paper - Fulfilling our potential: Teaching excellence, social mobility and student choice. Southampton: Author. 